\title{
CONCERNING A RESPONSE TO REINER MARIA RILKE'S DEATH: THE “RUSSIAN” P.S.
}

Rainer Maria Rilke, already in his lifetime, entered the canon of German literature, which quite early "appropriated" this Austrian poet, whose poems from the late 1910s - early 1920s were included in German school anthologies and discussed as "educational material" in specialized pedagogical journals. ${ }^{1}$ From 1899 to 1925, more than 100 reviews and over 200 articles and monographs on Rilke's work were published. ${ }^{2}$ Charming his readers with his poetic "loneliness", he was surrounded until his death by the enthusiastic attention of numerous admirers of both genders, for whom he became a real idol, which, in its turn, sometimes caused irritation in the literary milieu of his time ${ }^{3}$ resulting in ironic comments about the popularity of the poet with ladies, mostly.

This was precisely what the famous Austrian writer and influential literary critic Franz Blei (1871-1942) emphasized in his satirical "Literary Bestiary", where Rilke's name was used with the feminine article (Die Rilke) and his entire "characteristic" highlighted the "femininity" of the poet who was compared by the author to "a lap dog" - a favourite of "elderly women" who "constantly exalt it to the skies", which caused in the dog "a tendency to stick its nose into theological books, legends about Mary, and other things of that kind". 4

${ }^{1}$ For details see: Fritz B. Rainer Maria Rilkes Leser in Schule und Gesellschaft: Rezeption 1904-1936. Bern, 2009.

2 The first comprehensive review of Rilke's work was published in 1904, and the first dissertation was defended in 1913 at the University of Freiburg. See: Löwenstein S. Poetik und dichterisches Selbstverständnis: eine Einführung in Rainer Maria Rilkes frühe Dichtungen (1884-1906). Würzburg, 2004. S. 29; see also: Ritzer W. Rainer Maria Rilke Bibliographie. Wien, 1951

3 The established cult of Rilke caused irritation in later times, too. This found expression, for example, in the complete rejection of the poet in the post-war era among the German writers of the "Group 1947" and their supporters, by whose efforts Rilke was for some time fully forgotten. See about this: Demetz P. Noch einmal: “René Rilkes Prager Jahre" // Rilke: ein europäischer Denker aus Prag / Hrsg. von P. Demetz. Würzburg 1998 S. 10.

${ }^{4}$ Bestiarium Literaricum, das ist: Genaue Beschreibung derer Tiere des literarischen Deutschlands, verfertigt von Dr. Peregrin Steinhövel. München, 1920. S. 52. The second, expanded edition was published in 1922. Hereinafter, the translation is mine. - M.K.

This article is a translation of: M. Iu. Koreneva. Concerning a Response to Reiner Maria Rilke's Death: The «Russian» P. S. Russkaya literatura. 2021. № 1. P. 169-177. DOI: 10.31860/0131-6095-2021-1-169-177. 
Later, in an article on the death of Rilke, published on January 7, 1927 on the front page of the liberal newspaper "Die literarische Welt", Blei again returned to the theme of ladies' admiration of Rilke's poetry. ${ }^{5} \mathrm{~A}$ few years later it still bothered him: in his autobiographical book "A Story of a Life", published in 1930, he gives a detailed "portrait" of Rilke's nameless female readers, whom he compares to a large church community grouped around the poet, ${ }^{6}$ and in 1940, in Modern Portraits, he would deem it necessary to talk again about the "femininity" of Rilke and, as if justifying himself before his critics (primarily before Robert Musil) he would explain what he had meant in his old book and in the obituary. ${ }^{7}$ He left without comment his own jab at Rilke about the latter's "leaning towards theological books", since this "thesis", even with an ironic presentation, did not need any explanation or justification: since the publication of the "Book of Hours" ("Stundenbuch", 1905) which had been favourably received by critics, ${ }^{8}$ Rilke for many years enjoyed the fame of a religious poet, a "God-seeker", as Stefan Zweig called him in his review, ${ }^{9}$ the successor of the traditions of Angelus Silesius and Jacob Boehme, ${ }^{10}$ the creator of the "new mysticism" 11 and the voice of the new "spirituality". ${ }^{12}$

This readers' image of the "enlightened" poet was also visible in most of the responses to the death of Rilke, who died on December 29, 1926 in Switzerland.

The above-mentioned obituary by Blei, called by Walter Benjamin "bad and impudent", ${ }^{13}$ struck a note of discord against this background and provoked a response from Robert Musil, who, speaking at the Rilke's

${ }^{5}$ Blei F. Zu Rainer Maria Rilke // Die literarische Welt. 1927. Jg. 3. 7. Januar. № 15. S. 1.

${ }^{6}$ Blei F. Erzählung eines Lebens. Leipzig, 1930. S. 449.

${ }^{7}$ Blei F. Zeizgenössische Bildnisse. Amsterdam, 1940. S. 265-268.

815 reviews were dedicated to the first 1905 edition alone. For their list see: Fullenwider H.F. Rilke and his Reviewers: an annotated bibliography. Kansas, 1978. S. 31-32.

${ }^{9}$ Zweig St. Verse eines Gottsuchers // Nation. 1906. 9. Juni. № 36. S. 571-572.

${ }^{10}$ Hoffmann C. Das «Stundenbuch» von Rainer Maria Rilke // Die Zeit. 1906. 11. März. № 1242; Schaukal R. Rainer Maria Rilke // Nord und Süd: eine deutsche Montasschrift. 1908. Februar. Bd 124. № 371. S. 230-237.

${ }^{11}$ Scholz W. von. Neue Mystik // Der Tag. 1906. 2. August.

12 This view of Rilke as a religious poet also defined the editor's concept of his first collected works, which was published shortly after Rilke's death by the Insel publishing house (Rilke R.M. Gesammelte Werke: In 6 Bde. Leipzig, 1927). The owner of the publishing house Anton Kippenberg (1874-1950) consistently excluded from it everything that could somehow distort the sublime image of the poet (for details see: Eschenbach $G$. Ein Kulturautor im Klassikerverlag. Zur frühen Rezeptionsgeschichte Rainer Maria Rilke // Die Präsentation kanonischer Werke um 1900: Semantiken, Praktiken, Materialität / Hrsg.von Ph. Ajouri. Berlin; Boston, 2017. S. 31-42; for the history of the formation of this image of Rilke in the literary criticism of his time, see also: Löwenstein S. Poetik und dichterisches Selbstverständnis: eine Einführung in Rainer Maria Rilkes frühe Dichtungen (1884-1906). Würzburg, 2004. S. 29-32). Afterwards, in the 1950s, the issue of Rilke's religiosity became the subject of a heated debate, followed by a radical revision of pre-war assessments, which took place under the sign of the "demythologization" of Rilke's work (see: Sieburg $F$. Rilke, das Zeitsymptom // Sieburg $F$. Die Lust am Untergang Hamburg 1954 S. 337-356; Boehlich W. Lyrik als Religionsersatz Mir zur Feier: Rainer Maria Rilke // Spiegel 195628 März No. 13. S. 34-48).

${ }^{13}$ Ben'jamin V. Moskovskij dnevnik [The Moscow Diary] / Transl. by S. Romashko; ed. by M. Ryklin. M., 1997. p. 142. After reading this obituary on January 21, 1927, Benjamin on the same day began to write an objection to it, which, however, never reached the publication stage (published posthumously: Benjamin W. Rainer Maria Rilke und Franz Blei // Benjamin W. Gesammelte Werke: In 7 Bde / Hrsg. von T. Rexroth. Frankfurt a/M., 1972. Bd 4.1. S. 453. 
commemoration event on January 16, 1927 at the Berlin Renaissance Theatre, condemned his longtime friend Blei, as well as those who, like the poet Rudolf Borchardt (1877-1945) who did not include any of Rilke's poems in his anthology "The Eternal Stock of the German Poetry" ("Ewiger Vorrat deutscher Poesie") (1926) denied him an appropriate place on the poetic Olympus, and also those who had created the Rilke cult, distorting the very essence of his poetry. Muzil devoted a significant part of his sharply polemical speech to the "absolute perfection" of Rilke's poetry, the greatness of which, in his opinion, lies not so much in the religious feeling as in "a different vision": "He saw the world in a new, deeply internal way. And someday on the path that leads us from the religious worldview of the Middle Ages through the ideal of humanistic culture to the future image of the world, he will emerge not only as a great poet, but also as a great leader." 14 At the same time Musil was not the only one who used this sad event as an excuse to attack the cult of Rilke and defend his poetry. Before him, this was done by the Swiss poet and prose writer Robert Walser (1878-1956), who on January 4, 1927 published a deliberately artless poetic obituary, which, upon closer examination, turns out to be a kind of burlesque, aiming at Rilke's admirers who had annoyed him during his lifetime and finally left him at peace. ${ }^{15}$

In the same vein is one of the responses published in the newspaper "Rigasche Rundschau", although it differs in its message from the statements of Musil and Walser: if both writers, each in his own way, tried to protect Rilke from the readers, the Riga newspaper started to protect the readers from Rilke using some very unusual arguments.

This well-known daily newspaper, published in German in Riga in 1894-1939 and widely distributed beyond the Baltic region, organized a "first category" literary funeral for Rilke, to use the image of Musil, who in his speech complained that Rilke's death had not become a cause for national mourning and that all the responses in the press resembled a "second category" funeral - there were too few of them and they were printed in the "backyards" of the newspaper pages, according to Musil. ${ }^{16}$ It was certainly impossible to blame the "Rigasche Rundschau" for neglecting the event: only in the first few days after Rilke's death it published four articles related to his death - no periodical, either in Germany or outside of it, demonstrated such zeal in the sorrow. The first one

${ }^{14}$ Muzil' R. Rech' o Ril'ke [The Speech on Rilke] / Transl. by A.V. Belobratov // Muzil' R. Malaja proza. Izbr. Proizvedenija: V. 2 M., 1999. T. 2. P. 314.

${ }^{15}$ Walser R. Rilke // Prager Presse. 1927. 4. Januar. № 3. S. 6. For details on the ironic subtext of this poem see: Stiemer $H$. Feuilletonistische Reimereien auf «anspruchsvolle Jungen" und «hochgeschätzte Knaben». Der späte Robert Walser und die hohe Lyrik. Vortrag an der Jahrestagung der Robert Walser-Gesellschaft in Bern, 16. Oktober 2010 (https://www.robertwalser.ch/fileadmin/ redaktion/dokumente/jahrestagungen/vortraege/Stiemer-2010.pdf; date of access: 31.12.2020).

${ }^{16}$ Muzil' R. Rech' o Ril'ke. p.311. In fact, by the time Musil spoke, about 50 responses to Rilke's death had been published in German, Austrian and Swiss periodicals alone. For their list see: Schoolfield G.S. Rilke's last year. Kansas, 1966. P. 48-49. They continued to appear after the Berlin evening and their number and variety of genre forms (poems, critical studies, scholarly articles, etc.) clearly did not correlate with Musil's subjective sentiment. For more on the reaction to Rilke's death see: Panthel H.-W. Bibliographie zu Rilkes Tod: Erste Stimmen der Freunde, Kritiker und Feuilletonisten aus den Jahren 1926-1928 // Blätter der Rilke-Gesellschaft. 1982. Bd 9. S. 111-127; Panthel H.-W. Poetische Nekrologe zu Rainer Maria Rilkes Tod // Literaturund-Kritik.1986. H. 201/202, Februar-März. S. 71-85; Panthel H.-W. Materialien zu Rainer Maria Rilkes Tod: Miszellen zur Rezeption seines Werkes der Jahre 1926-1928. Bonn, 1982. 
was a short piece in the "Latest News" section in the December 30, 1926 issue. ${ }^{17}$ The next day a lengthy, heartfelt obituary appeared, signed by the newspaper staff journalist Walter Falke, who, in full accordance with the genre, gave a general characteristic of Rilke's work, noting his "religious feeling “ (significant for many readers), presented a brief biographical outline, mentioning the poet's trip to Russia, with which, as Falke wrote, he was connected by a "deep kinship", and, summarising Rilke's life, pointed out that by the end of his life the poet was pervaded with the hatred of Germany. "The reasons for this tragic turn in his mindset are more than obvious," the author notes at the end of the article, before moving on to the last "formal" phrase, with the words of gratitude to Rilke, who "will continue to live in his books". ${ }^{18}$

This obituary, which in its tone did not stand out too much in the bulk of responses (though its somewhat unexpected ending attracted attention) was immediately followed by another one - this time in verse. In the first issue of 1927 an octave by Elfriede Skalberg (Eckardt-Skalberg, 1884-1964), a well-known German poet and translator of Latvian poetry into German from Riga, was published. ${ }^{19}$ Entitled with an emphatic intimacy "Rainer Maria", this poem was an elegant paraphrase of the poem "Self-portrait of 1906" by Rilke, inspired by a portrait by Paula ModersohnBecker (1876-1907) and included in the cycle "New Poems" ("Neue Gedichte", 1907). The name of Elfrida Skalberg had long been familiar to the readers of the "Rigasche Rundschau" — she had made her debut there in $1902,{ }^{20}$ later becoming a regular author. She published poems, articles and book reviews, including by Russian authors, among which she singled out M.A. Voloshin, comparing his poetry with the poetry of Rilke: "The combination of the Russian" broad nature " (in the text in Russian - M.K.) with the most refined Western culture of verse and the simple, expressive style brought to perfection, which can only be found in Rilke, produce a captivating impression", Skalberg wrote in a long review of Voloshin's collection "Deafmute Demons", published in the second edition in the publishing house "Knigoizdatel'stvo pisatelej v Berline" in 1923 and of his "Verses on Terror" 21 published there at the same time.

In November 1927 in Riga there would be celebrations of the 25 th anniversary of Skalberg's literary activity, which would be covered in detail by the Baltic German-language press, including the newspaper "Rigasche Rundschau", which on the occasion of the anniversary published an essay on her life and work authored by the newspaper's editor-in-chief Paul Schiemann (1876-1944), a well-known political writer, prominent Latvian politician, deputy of the Latvian Seim. ${ }^{22}$ This essay highlighted the

17 Rigasche Rundschau. 1926. 30. Dezember. № 294. S. 7.

${ }^{18}$ Falke W. Zum Tod Rainer Maria Rilkes // Rigasche Rundschau. 1926. 31. Dezember. № 295. S. 5.

${ }^{19}$ In the 1940s she would begin to translate from Russian into German; in her translation I.A. Krylov's fables (1948) and A. Pushkin's "Eugene Onegin" (1947, 1964) would be published. In 1949 Skalberg emigrated to Germany. For more details, see Lexikon der deutschsprachigen Literatur des Baltikums und St. Petersburgs / Hrsg. von C.L. Gottzmann, P. Hörner. Berlin; New York, 2007.

${ }^{20}$ Illustrierte Beilage der Rigaschen Rundschau. 1902. 1. December. № 12. S. 103.

${ }^{21}$ Eckardt-Skalberg E. Russische Emigrantenlyrik // Rigasche Rundschau. 1924. 7. April. № 81. S. 6.

${ }^{22}$ For details see: Hatlie M.R. Riga et War 1914-1919: War and Wartime Experience in a Multi-ethnic Metropolis. Marburg, 2014. P. 218-221; Lexikon der deutschsprachigen Literatur des Baltikums und St. Petersburgs / Hrsg. von C.L. Gottzmann, P. Hörner. Berlin; New York, 2007. Bd 3. S. 1129-1132. 
role of Skalberg in the formation of the original German "Baltic poetry", independent of both the "dubious geniuses of the West and the North," and of the "literary schools of Moscow," where Skalberg had spent some time. ${ }^{23}$ The publication of her lyrical obituary to Rilke's death was something of a sign of high respect for the deceased poet, to whom supposedly the best representative of the new generation of "Baltic literature" which, according to Paul Schiemann, spoke a new language and "made art an integral part of life", dedicated her poems. ${ }^{24}$ It would seem that all the "funeral" genres were exhausted: a short news piece, a classic obituary by V. Falke, and Skalberg's lyrical poetic response - there were enough of texts befitting the occasion and the topic might not be resumed anymore. Nevertheless, two days after the publication of Skalberg's poem and a week after Rilke's death, the newspaper published another material related to the poet's name: on January 5, 1927 his "Letter to a Russian Aristocrat" was published, "provided to the editorial board by courtesy" of the autograph collector Mary Stakle (1877 - after 1940), ${ }^{25}$ according to the editorial note. This letter, written by Rilke on December 22, 1900 and addressed to Prince Sergey Ivanovich Shakhovskoy (1865-1908) is widely known today: it was reproduced in 1969 by S.V. Zhitomirskaya from the original ${ }^{26}$ stored in the MS Division of the Russian State Library ${ }^{27}$ where it had arrived, according to the catalogue, ${ }^{28}$ from a certain Maksimov from Riga in 1948. It was later included in the Russian translation into the book "Rilke and Russia" edited by K.M. Azadovsky, who in the commentary mentioned its first publication in "Rigasche Rundschau". ${ }^{29}$ The newspaper publication was not only the first publication of this letter, but the first and by that time the only publication, presented to the general public, of an epistolary document testifying to Rilke's direct personal contacts with his Russian contemporaries. Most of this letter is devoted to the analysis of G. Hauptmann's play "Michael Kramer" (1900), the dress rehearsal of which at the Berlin "German Theater" Rilke visited on December 19, 1900 and which made an indelible impression on him. The Russian theme in the letter is only fleetingly mentioned: Rilke informs Shakhovsky about his studies of Alexander Ivanov's work, towards the end he writes that he often thinks "of Moscow as his homeland", and then ends the text with a passage written in Russian (with some errors): "I often already think in Russian, and thoughts of this kind are very difficult to express in German, because there is nothing simple, heartfelt in this language, so it seems completely impossible to pray with German

${ }^{23}$ Schiemann P. Elfriede Skalberg zum 25-jährigen Dichterjubiläum // Rigasche Rundschau. 1927. 15. November. № 258. S. 5.

${ }^{24}$ Ibid.

${ }^{25}$ Ein Brief R.M. Rilkes an einen russischen Aristokraten // Rigasche Rundschau. 1927. 5. Januar. № 3. S. 2. Biographical information on Mary Stakle could not be found.

${ }^{26}$ Pis'mo R.M. Ril'ke k kn. S.I. Shahovskomu [Rilke's letter to Shakhovskoy]/ Publ. by S.V. Zhitomirskaya // Zapiski otdela rukopisej GBL. M., 1969. Vol. 31. pp. 240-248.

${ }^{27}$ RGB [Russian State Library]. F. 218. № 39.6.

${ }^{28}$ See: RGB[Russian State Library]. Opis' fonda 218 [Catalogue of Collection 218] (Otdel rukopisej.Sobranie). vol. 1 (№№ 7-119). p. 57.

${ }^{29}$ Ril'ke i Rossija: Pis'ma. Dnevniki. Vospominanija. Stihi [Rilke and Russia; Letters. Diaries. Memoirs./ Ed. by K.M. Azadovskij. SPb, 2003. pp. 359-362. 
sounds." 30 The editors of the "Rigasche Rundschau" felt it was necessary to preface this entirely "innocent" publication with an explanation, the aim of which, according to the author's intention, was to expand the context of the private document cited here. "This letter," according to the preface, "is undoubtedly of extraordinary interest in the literary and psychological respect, and not only in relation to Rilke, but above all in relation to the German literary world as a whole, with its passionate enthusiasm for Russians, which reaches the level of national pathological masochism, reaching its climax already at the turn of the century and continuing to rage today, with almost the same unrelenting force. We recommend that our readers, after reading our publication, turn to the book "Sir Galahad. A Guide to the Idiots of Russian Literature" 31 published by Albert Langen. Then followed the text of the letter.

The recommended book, which had a dedication to the "solid foundations of the world" (literally "the ridge of the world"), ${ }^{32}$ did not need advertising: published in 1925 with a huge print run of 20,000 copies by the reputable Munich publishing house of Albert Langen, which published, among other things, the famous satirical magazine "Simplicissimus", it immediately attracted attention, provoking a mixed reaction - outrage in the Russian émigré press ${ }^{33}$ and approval in the German press. One of those who greeted this book with enthusiasm was, e.g., the famous writer Carl von Ossietzky (1889-1938), a pacifist and Nobel Peace Prize laureate (1935), who later died from the consequences of imprisonment in a concentration camp. In the left-liberal weekly "Tage-Buch" he published a review in which, strongly recommending this essay to readers, he called the Guidebook "a brilliantly performed attack on Russian literature from Pushkin to Gorky and on Russian essence from Rurik to Lenin, on the deification of Tolstoy and Dostoevsky outside Russia ", and described the book's editor as "a passionate European mind endowed with high pathos and humour who was able to show that "Russia is not fate, not a religion, not an image, but a drowsy state of an amorphous mass, with the

${ }^{30}$ Ril'ke i Rossija. P. 361, 362. In "Rigasche Rundschau" this fragment is also reproduced in Russian (with a German translation), but the spelling of some words is different from the way it is given in the publication by S.V. Zhitomirskaya.

${ }^{31}$ Ein Brief R.M. Rilkes an einen russischen Aristokraten. S. 2.

32 Sir Galahad. Idiotenführer durch die russische Literatur. Gewidmet dem Rückgrat der Welt. München, 1925. The title of this book is translated into Russian differently in different sources: "A Guide to the Idiotism of Russian Literature", "A Guide to Russian Literature for Idiots", a freer version of "The Idiocy of Russian Literature: A Guide" is also possible. In this article, preference is given to the "Guide to the Idiots of Russian Literature" version, since the author personifies this "phenomenon" and gives in her book a gallery of portraits of Russian literary "idiots", just as other German authors would later do, who picked up B. Eckstein-Diener's satirical genre for characterizing individual representatives of the political and social life of Germany in the 1960-1990s (H.M. Enzensberger, G. Rezzori, etc.)

${ }^{33}$ See, for example: Vyzyvajushhaja kniga [A Provocative Book]// Rul'. 1926. March 24. № 1614. The memory of this book remained for a long time: almost a quarter of a century later, A.I. Ilyin in his article "Haters of Russia" (1953) would write about it calling the Guide "an obscene lampoon" (Ilyin A.I. Nashi zadachi: Stat'i 1948-1954 gg.: V 2 t. [Our Tasks: Articles 1948-1954: In 2 Vols]. Vol. 2. P. 533. Paris, 1956. (In Russ.)), and almost at the same time N. Lossky in the work "The Character of the Russian People" (1957), mentions the Guide (among others) as an example of "rabid hatred" of Russia and "a sample of the blindness to which hatred leads" (Lossky N.O. Usloviia absoliutnogo dobra: osnovy etiki. Kharakter russkogo naroda [Conditions of Absolute Goodness: Fundamentals of Ethics. The Character of the Russian people]. Moscow, 1991. pp. 280-281. 
dull life of the body and the unrinsed soul." 34 "The gospel of Russia has ceased to be untouchable. The criticism has begun," Ossietzky concluded. ${ }^{35}$

The author of the Guide was the well-known and popular writer Bertha Eckstein-Diener (1874-1948), who wrote under the pseudonym Sir Galahad and who became famous primarily for historical novels and essays on the history of culture. Her pronouncement on the "Russian question" was rather unexpected and fell out of the general context of her work if only by its accusatory pathos towards the Russian culture, which she described, in terms of racial theory, as a product of an inferior race, unable to produce anything of its own and dependent on the "world Jewry". Supporting her opinion by numerous quotations from various sources, including the Russian ones (I.V. Kireevsky, N.K. Mikhailovsky, M.A. Bakunin, A.V. Lunacharsky, etc.), which give the impression of the seriousness of the presented "research" and the author's wide knowledge, Eckstein-Diner gives an outline of the history of Russia from the Varangians to Lenin, and, briefly describing those representatives of Russian literature that Russians are so proud of (Pushkin, with his "Negro blood" and "boring" Eugene Onegin", "Tatar Turgenev", "Satanist Lermontov", etc.), she focuses on the figure of Dostoevsky, who, according to the Guide, expelled the "hero" from literature and imposed the "ideal of an idiot", thereby opening the way to the "world persecution of noble people and nobleness as such. ${ }^{36}$ " It is in Dostoevsky that the author sees the main proponent of the expansive barbarian spirit, who also demands that "everyone should become Russian." The respective quotation from the "Diary of the Writer for 1877", 37 published in the volume of "Political Writings" of the German collected works of Dostoevsky, ${ }^{38}$ is used as the epigraph and then repeated in the text as a starting point for the subsequent proof of the danger posed by Russian culture with its claims to religious and spiritual domination and total Russification of Europe, as Eckstein-Diener showed, relying on a phrase taken out of context.

For such a fierce attack on the cultural enemy in the person of Dostoevsky, Eckstein-Diener, a writer of harsh style, had her own reasons and causes. One of the reasons was Dostoevsky's permanent presence in the German cultural space of the early 20 th century, ${ }^{39}$ which irritated not

34 Tage-Buch. 1926. 13. März. № 11. S. 432.

35 Ibid.

${ }^{36}$ Sir Galahad. Idiotenführer durch die russische Lietratur. S. 132.

${ }^{37}$ In his article "We Are but Useless Wretches in Europe"” Dostoevsky, addressing Russians, wrote that Europe's contempt for Russians is caused by Russians' contempt for themselves when compared with Europe, and that respect can only be regained by one thing: "If humanity is a national idea, a Russian idea then everyone should become Russian, become oneself $<$... $>$ To become Russian means to stop despising one's own people "(Dostoevsky F.M. Dnevnik pisatelja (Writer's Diary): In 2 volumes. M., 2011. V. 2 / Comment. by A.I. Batyuto, A.M. Berezkina, V.E. Vetlovskaya, E.I. Kijko, G.V. Stepanova, V.A. Tunimanov. P. 28).

${ }^{38}$ Dostojewski F.M. Sämtliche Werke: In 22 Bde / Unter Mitarbeiterschaft von Dmitri Mereschkowskis; hrsg. von A. Moeller van der Bruck. München; Leipzig, 1907. Bd 13. Politische Schriften / Mit einer Einleitung von Dmitri Mereschkowski; Übertr. von E.K. Rahsin. S. 223.

${ }^{39}$ Apart from the famous collection of Dostoevsky's works in 22 volumes of Pieper's publishing house, published in 1906-1919, there was a collection in 25 volumes, published in 1921-1922 by the Leipzig publishing house Insel (after a grand celebration of Dostoevsky's centenary in Germany in 1921), and in 1923 the publishing house "Hesse \& Becker" began publishing another collected works in 18 volumes, in new translations. In addition, individual works by Dostoevsky were regularly published: from January 1926 to September 1927 alone, 16 Dostoevsky's books 
only Eckstein-Diener. ${ }^{40}$ The immediate reason was, probably, the acquisition of Dostoevsky's manuscripts from the Soviet Union by the Austrian writer Rene Fülöp-Miller (René Fülöp Miller, 1891-1963) in 1923-1924. ${ }^{41}$ This event was widely discussed in the German press, ${ }^{42}$ and in 1925 Piper - Verlag publishing house already published the first volumes of archival materials from the "Dostoyevsky's Heritage" series ("Dostojewski-Nachlass"). ${ }^{43}$ One of those who financed this "project", which cost 30,000 marks, and helped to organise it, was Friedrich Eckstein (1861-1939), a famous philanthropist, President of the Vienna Theosophical Society (since 1887), friend of Z. Freud and G. Meyrink, acquaintance of R. Steiner, E. Blavatsky, H. von Hofmannsthal, R. Musil, K. Kraus, A. Schnitzler, F. Werfel and many other representatives of the Austrian artistic, literary and musical world, the Viennese "legend" and ex-husband of Bertha Eckstein-Diener, who since the divorce was at war with him. ${ }^{44}$ Eckstein is indicated as the co-publisher of the series, which, according to Bertha Eckstein-Diener, was nothing more than the result of a "conspiracy of Jewish-Bolshevik People's Commissars" who deliberately sent Dostoevsky's manuscripts to the West to corrupt European morality to the delight of the "Jew who rubs his hands and laughs." 45 The fact that the writer had her own purely personal motives that prompted her to denounce German Russophilia in general and her ex-husband's contribution in particular, undoubtedly determined the stylistic tension of her openly racist, anti-Semitic book. However, even if these ideas were pronounced in a more decent, restrained manner, it would still be obvious

were published in various publishing houses in Berlin, Leipzig, Stuttgart, Munich, Wolfenbüttel with the participation of different translators (see: Jonas H. Bibliographie // Osteuropa 1928. Bd 3. No. 5. Februar. S. 398-399) Each book, in its turn, was discussed in the press, not to mention dozens of research studies devoted to Dostoevsky. "The number of anthologies, collections and other publications on Dostoyevski is growing with a threatening speed," wrote Arthur Luther, a well-known translator of Russian literature, in his article "Dostoyevsky Has No End" (Luther A. Dostojewski und kein Ende // Das literarische Echo. 1923. H. 17-18. S. 953). For more details see: Dudkin V.V., Azadovsky K.M. Dostoevskij v Germanii [Dostoevsky in Germany] (1846-1921) // Lit. nasledstvo. [Lit. inheritance] 1973. T. 86. F.M. Dostoevskij: Novye materialy i issledovanija[New materials and research] pp. 700-716, 725-727; Gerigk H.-J. Dostojewskij, der “vertrackte Russe”. Die Geschichte seiner Wirkung im deutschen Sprachraum vom Fin de siucle bis heute. Tübingen, 2000.

${ }^{40}$ See, for example, Franz Blei's opinion in a letter to Karl Schmitt: “... everything is Russian, and especially Dostoevsky, for $<\ldots>$ the Germans is great evil, they would be Anglicized, they were drawn to the light, and not to the gloomy Christianity, Russia drives out the remnants of the German spirit from the minds" (Blei F. Briefe an Carl Schmitt 1917-1933 / Hrsg. von A. Reinthal in Zusammenarbeit mit W. Kühlmann. Heidelberg, 1995. S. 64).

${ }^{41}$ For more details see: Bogdanova O.A. Kakie rukopisi Dostoevskogo byli v «Piper-Verlag»? [What were Dostoevsky's manuscripts in Piper-Verlag?] // Neizvestnyj Dostoevskij [The Unknown Dostoevsky]. 2016.Vol. 3. No. 2.P. 54-69.

42. Deutsche Allgemeine Zeitung. 1922. 23. Februar. № 92.; Berliner Tagebatt. 1924. 19. Oktober. № 498; Berliner Tagebatt. 1924. 30. November. № 569; Rigasche Rundschau. 1925. 28. März. № 71; Vossische Zeitung. 1925. 16. August. № 196; Frankfurter Zeitung. 1926.8. August. № 585, и др.

43 Dostojewski am Roulette (Dostoevsky at Roulette), Die Lebenserinnerungen der Gattin Dostojewskis (Memoirs of Dostoevsky's Wife), Tagebuch der Gattin Dostojewskis (Diary of Dostoevsky's Wife). Until 1931, Piper-Verlag published five more volumes.

44 Schmid U. Die Dostojewski-Rezeption im deutschen Nationalsozialismus // Jahrbuch der Deutschen Dostojewskij-Gesellschaft / Hrsg. von M. Schult. Flensburg, 2007. Bd 14. S. 49.

45 Quoted from: Mulot-Déri S. Sir Galahad. Porträt einer Verschollenen. Frankfurt a/M., 1987. S. 210. 
that the complex of "ideas" presented in the Guidebook, in tune with Hitler's theses outlined in "Mein Kampf" (1925-1926), was perceived as acceptable even outside the National Socialist movement long before it formed the basis of the state ideology of Germany: Bertha EcksteinDiener was by no means one of those who would actively support the Nazi regime, of which she spoke out quite critically. ${ }^{46}$ The liberal Riga newspaper "Rigasche Rundschau" was in no way connected with the ideological circle of German nationalists and until the very departure of Editor-inchief Paul Schiemann from his post in June 1933 (for ideological reasons) it quietly resisted the emerging "the people's", and then " the people's political movement" in Germany, ${ }^{47}$ while in relation to Russia it showed distant restraint, at the same time devoting a lot of materials to the issues of Russian current politics and culture, allowing itself, at best, ironic comments with the observance of "language decency". The preface to Rilke's letter fell out of this general tone both in its style and in its message, which did not match the memorial context. And even though this "preface" was published as an editorial, it is unlikely that Paul Schiemann was its author. Even in his article "Asianization of Europe" ("Asiatisierung Europas», 1919), published in Germany, where he, still a Russian subject, found himself at the end of the war - even in this article, meant to warn the "blind cultural world" of Europe against the RussoAsian deceit, clad in the "mantle of bits and pieces of European ideas",48 Schieman, with all the polemic sharpness of the text aimed against Bolshevism, maintained "stylistic neutrality" and did not look for the source of his concern in Russian literature. Its influence on German culture did not seem to bother him at all: he would devote to this topic his speech at the commemoration event of V.G. Korolenko (1853-1921), organized on the occasion of the writer's death on January 22, 1922, by the Russian University Courses in Riga. ${ }^{49}$ It is more likely that the author of the preface to Rilke's letter was Guido Hermann Eckardt (1873-1951), poet and prose writer, literary and theatre critic, head of the culture section of the Rigasche Rundschau, ${ }^{50}$ where he would soon publish his large flattering review of the book "Mothers and Amazons" ("Mütter und Amazonen", 1932) by Bertha Eckstein-Diener, whom he called "a brilliant writer". ${ }^{51}$ An influential journalist who played an important role in the cultural life of Riga in that time, a graduate of the University of Munich, closely associated with the literary "bohemian" circles of Munich, he

46 Ibid. S. 261.

${ }^{47}$ Kause $H$. Der publizistische Widerstand Paul Schiemanns gegen den Nationalsozialismus in den deutschen Volksgruppen // Deutsch-Balten, Weimarer Republik und Drittes Reich / Hrsg. von M. Garleff. Köln; Weimar; Wien, 2001. Bd 1. S. 197-216.

48 Schiemann P. Die Asiatisierung Europas. Gedanken über Klassenkampf und Demokratie / Hrsg. vom Generalsekretariat zum Studium des Bolschewismus. Berlin, 1919. S. 8, 9.

${ }^{49}$ Russkie universitetskie kursy v Rige (kratkij otchet o dejatel'nosti) [Russian university courses in Riga (brief activity report] Riga, 1922. p. 6.

50 See about him: Lukas L. Literary Queer Mésalliances in Riga around $1900 / /$ Queer Stories of Europe / Ed. by K. Vērdiņš, J. Ozoliņš. Cambridge, 2016. P. 110-111, 119-121; Mattiesen $H$. Der Anteil der Deutschbalten am Münchener Kulturleben im 19. Und am Anfange des 20. Jahrhunderts // Baltische Hefte. 1961. № 1. S. 170-190; H. v. R. Guido Hermann Eckardt [Nekrolog] // Baltische Blätter. 1952. № 1. S. 6; Lexikon der deutschsprachigen Literatur des Baltikums und St. Petersburgs / Hrsg. von C.L. Gottzmann, P. Hörner. Berlin; New York, 2007. Bd 1. S. 380.

${ }^{51}$ Rigasche Rundschau. 1932. 27. Februar. № 46. S. 9. 
was known as a convinced "Westerner" and was not afraid to "denigrate respected, famous men of the good old art", as Paul Schiemann would write about him in the abovementioned essay about Elfrida Skalberg, the wife of Guido Hermann Eckardt. ${ }^{52}$ It is possible that here, as in the case of Bertha Eckstein-Diener, we see an exchange of "family" remarks, and the subtext of the preface to Rilke's letter contains a jab addressed to Elfrida Skalberg with her Russian connections and her obvious love for Rilke, who for the first time after the publication of the "Book of Hours" in 1905 was "ideologically" correlated with Russia in a wide public space, outside of scholarly research where this topic had already been present. This connection is obvious today but it was not so obvious to the readers of 1927, since Rilke's Russian motives scattered throughout his various texts did not make into a single picture, while his personal contacts with Russia were still a fact of his private biography. The fact that this connection in this particular case was presented almost as cultural guilt, not even in the form of a personal statement, but in an anonymous, "editorial" form, in a mocking style, without regard to the newspaper's reputation and clearly counting on the understanding of the audience, proved that the audience was satiated with Russian culture and ready to accept the image of a cultural enemy. The personification of the enemy, for the first time paired with Rilke, was Dostoevsky with his stirring moral and religious themes, This conjunction of the two "symptoms of the era", which was content with "poetic religiosity" instead of "true faith", as the literary critic F. Sieburg would later say about the pre-war cult of Rilke, ${ }^{53}$ was a sign of an intense cultural anxiety. This degree of the anxiety was so significant that even Rilke's death became not an "excellent excuse" for "the roaring salute of obituaries" as Musil bitterly observed in his speech, ${ }^{54}$ but an excuse for expressing fear of the threat of a symbiotic fusion of German and Russian cultures on religious grounds.

\footnotetext{
52 Schiemann P. Elfriede Skalberg zum 25-jährigen Dichterjubiläum. S. 5 .

${ }_{53}$ Sieburg F. Rilke, das Zeitsymptom. S. 354.

${ }^{54}$ Muzil R. Rech' o Ril'ke. p. 314.
} 